\title{
Recyclable Insulating Foams for High Temperature Applications ${ }^{+}$
}

\author{
Lucía Doyle ${ }^{1, *}$ and Ingo Weidlich ${ }^{2}$ \\ 1 HafenCity University 1, 20457 Hamburg, Germany; lucia.doyle@hcu-hamburg.de \\ 2 HafenCity University 2, 20457 Hamburg, Germany; ingo.weidlich@hcu-hamburg.de \\ * Correspondence: lucia.doyle@hcu-hamburg.de; Tel.: +49-40-42827-4590 \\ + Presented at the First International Conference on “Green" Polymer Materials 2020, 5-25 November 2020; \\ Available online: https://cgpm2020.sciforum.net/.
}

Published: 4 November 2020

\begin{abstract}
The recently approved restriction on diisocyanates highlights the health and safety issues concerning polyurethane manufacturing and the relevance of developing sustainable insulating polymeric foams. This is particularly challenging for applications where the foam is subjected to high temperatures $\left(>80^{\circ} \mathrm{C}\right)$ and bear loads, such as insulating and bonding material for district heating pipes. As part of a PhD project concerning pre-insulated district heating pipes for the circular economy, polybutylene (PB-1) has been identified as a promising candidate for the application, due to its low thermal conductivity, high temperature mechanical properties retention, excellent environmental stress cracking resistance (ESCR) and outstanding creep resistance. It is a recyclable thermoplastic and of non-toxic nature, pre-requisites for circular product development. On the contrary to other polyolefins, PB-1 is reported to strain-harden and has high melt strength, required properties for foaming. The purpose of the study is to assess the foamability of PB-1 through extrusion foaming experiments. A twin-screw extruder was used with varying concentrations of a chemical blowing agent. The obtained samples have been characterised for density, expansion ratio and microstructure. Foams with a volume expansion ratio of 1.8 were achieved. The results confirm the foamability of this polymer. The increase of the die pressure and its contribution to strain hardening were identified as key parameters for successful foaming. Further research will include improving the expansion ratio with a physical blowing agent and mechanical characterization of the foam.
\end{abstract}

Keywords: polymeric foam; polybutylene; district heating; insulation; thermoplastic; circular economy

\section{Introduction}

District heating $(\mathrm{DH})$ is called to be a cornerstone element towards decarbonizing the heating sector. Thanks to a district heating network, the use of decentralized renewable and waste heat sources is enabled. For its technical and economic feasibility, correct insulation of district heating pipes is critical. As for state of the art, all district heating pipes are insulated with polyurethane foam (PU) [1].

PU foams present the lowest thermal conductivity among foamed polymers used commercially [2]. While PU has excellent thermal and mechanical properties, it has important environmental and toxicity drawbacks, which trigger the need for research in new and alternative insulating foams.

PU is produced from a ca. 50/50 mix of a polyol and either TDI (toluene diisocyanate) or MDI (methylene diphenyl diisocyanate). TDI and MDI are classified as suspected of causing cancer, as dermal and respiratory sensitizers, for acute toxicity following inhalation, as well as eye, skin and 
respiratory irritants under the EU's CLP Regulation [3]. The European Commission has aproved to restrict the use of diisocyanates to a concentration limit of $0.1 \%$ by weight under REACH on 4 August 2020 [4].

There is a need for developing environmentally friendly insulating foams following a holistic approach: conceptualized from the beginning out of non-toxic and recyclable materials and a safe manufacturing process. In this context, the foamability of PB-1 is explored. Promissing properties for the application are its low thermal conductivity of $0.114 \mathrm{~W} / \mathrm{mK}$ [5], high temperature mechanical properties retention, excellent environmental stress cracking resistance (ESCR) and outstanding creep resistance [6]. It is a recyclable thermoplastic and of non-toxic nature, pre-requisites for circular product development. On the contrary to other polyolefins, PB-1 is reported to strain-harden and has high melt strength [6], required properties for foaming [7]. However, its foaming behaviour has not been found reported in the open literature. In this study the foamability of PB-1 is studied through extrusion foaming experiments with a chemical blowing agent. The obtained samples have been characterised for density, expansion ratio and microstructure. Foamability is assessed in terms of achieved volume expansion ratio, microstrucure and processing window using available extrusion equipment. Optimization of the foaming process is out of the scope of this study. The presented results are part of a larger screening of commertial PB-1 grades.

\section{Experiments}

\subsection{Materials}

Toppyl PB0110M PB-1 from LyondellBasell was extrusion foamed using Hydrocerol CT 550 chemical blowing agent (CBA), kindly provided by Clariant.

\subsection{Extrusion Foaming Process}

The extrusion process was undertaken with a twin screw ZSE 27 MAXX extruder (Leistritz Extrusionstechnik $\mathrm{GmbH}$, Nürnberg, Germany), with $\mathrm{D}=28.3 \mathrm{~mm}, \mathrm{~L} / \mathrm{D}=48$, and 12 modular barrels with $2.1 \mathrm{~kW}$ heating power each and water cooling. A strand die with 3 strands of $4 \mathrm{~mm}$ diameter each was used. The feeding temperature was set as low as possible as to create a melt seal and avoid premature degassing of the $\mathrm{CBO}$, which was set at $140{ }^{\circ} \mathrm{C}$. The temperature was progressively increased up to $175^{\circ} \mathrm{C}$ after the $\mathrm{CBO}$ dosing point, which as to allow its complete decomposition, and then progressively lowered. The amount of dosed CBO was varied from 4.2 to $10 \% \mathrm{wt}$., for die exit temperatures of 110 and $115{ }^{\circ} \mathrm{C}$. Screw speed rate and feed rate were kept constant to $100 \mathrm{rpm}$ and 4 $\mathrm{kg} / \mathrm{h}$ respectively.

\subsection{Foam Characterization}

The foam samples were randomly collected at each processing condition after achieving the stedy state and characterized for density, volume expansion, cell size and cell density.

The density was determined with a $100 \mathrm{~mL}$ glass pycnometer, destilled water and a Sartorius AC 211 S (Goettingen, Germany) balance.

Foam volume expansion ratio is often determined as the ratio between the density of the polymer and the density of the foam. However, since a CBO is used, for which $70 \% \mathrm{wt}$. are effective foaming components, and up to $10 \%$ wt. CBO was dosed, this results in the addition of $3.3 \%$ wt. of the decomposition products. It was found more accurate to determine the volume expansion ratio $V_{\text {exp }}$ as

$$
\mathrm{V}_{\text {exp }}=\frac{\text { diameter foam extrudate }}{\text { diameter polymer extrudate }}
$$

in an analogous method as used by [8].

The diameter of the obtained foam samples and neat polymer extrudates where obtained from photographs taken using a Nikon D700 camera and a tripod. Photographs were recorded from immediately after collection (time between collection and initial photo max $20 \mathrm{~s}$ ) up to over $2 \mathrm{~h}$ after 
extrusion, in $20 \mathrm{~s}$ time-laps intervals. The diameter of each strand was measured in 5 different locations of each strand once its dimension was stable using Fiji [9]. The average of the five measurements is presented in each case.

The morphology of the foams was examined in an optical microscope (Leica DMLP, Wetzlar, Germany). Cell size was measured from the obtained micrographs using Fiji [9]. Cell population density $\left(\mathrm{N}_{0}\right)$, defined as the number of cells per unit volume of the original unfoamed polymer, was calculated as $[10,11]$ :

$$
\mathrm{N}_{0}=\left(\frac{\mathrm{n}}{\mathrm{A}}\right)^{3 / 2} \cdot V_{\exp }
$$

where $\left(\mathrm{N}_{0}\right)$ is the cell population density $\left(\mathrm{cell} / \mathrm{cm}^{3}\right), \mathrm{n}$ is the number of cells in the micrograph and $\mathrm{A}$ the area of the micrograph $\left(\mathrm{cm}^{2}\right)$.

\section{Results and Discussion}

The density of the obtained samples are presented in Table 1:

Table 1. Density for samples under different process conditions.

\begin{tabular}{ccc}
\hline die T $\left({ }^{\circ} \mathrm{C}\right)$ & CBO \% wt. & Density $(\mathrm{g} / \mathrm{mL})$ \\
\hline 110 & 4.2 & $0.740 \pm 0.032$ * \\
110 & 7.1 & $0.5 \pm 0.017^{*}$ \\
110 & 8.50 & $0.598 \pm 0.031$ * \\
110 & 10 & $0.53 \pm 0.034 *$ \\
115 & 4.2 & $0.508 \pm 0.122 *$ \\
115 & 7.1 & $0.508 \pm 0.036^{*}$ \\
115 & 8.50 & $0.488 \pm 0.178^{*}$ \\
115 & 10 & $0.601 \pm 0.089 *$ \\
\hline
\end{tabular}

* Standard deviation.

The determined volume expansion ratio, cell population density and cell size and their relation with the process conditions can be found in Figure 1:
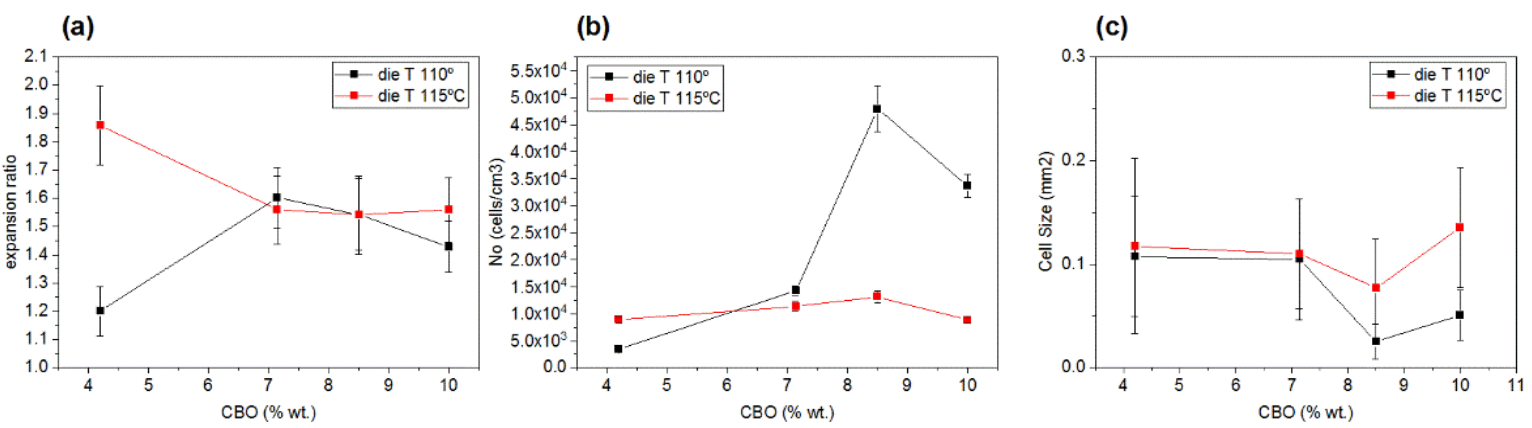

Figure 1. (a) expansion ratio vs introduced amount of CBO. (b) Cell population density vs introduced amount of CBO. (c) Cell size vs. introduced amount of CBO.

Representative micrographs for each process condition can be found in Figure 2. 

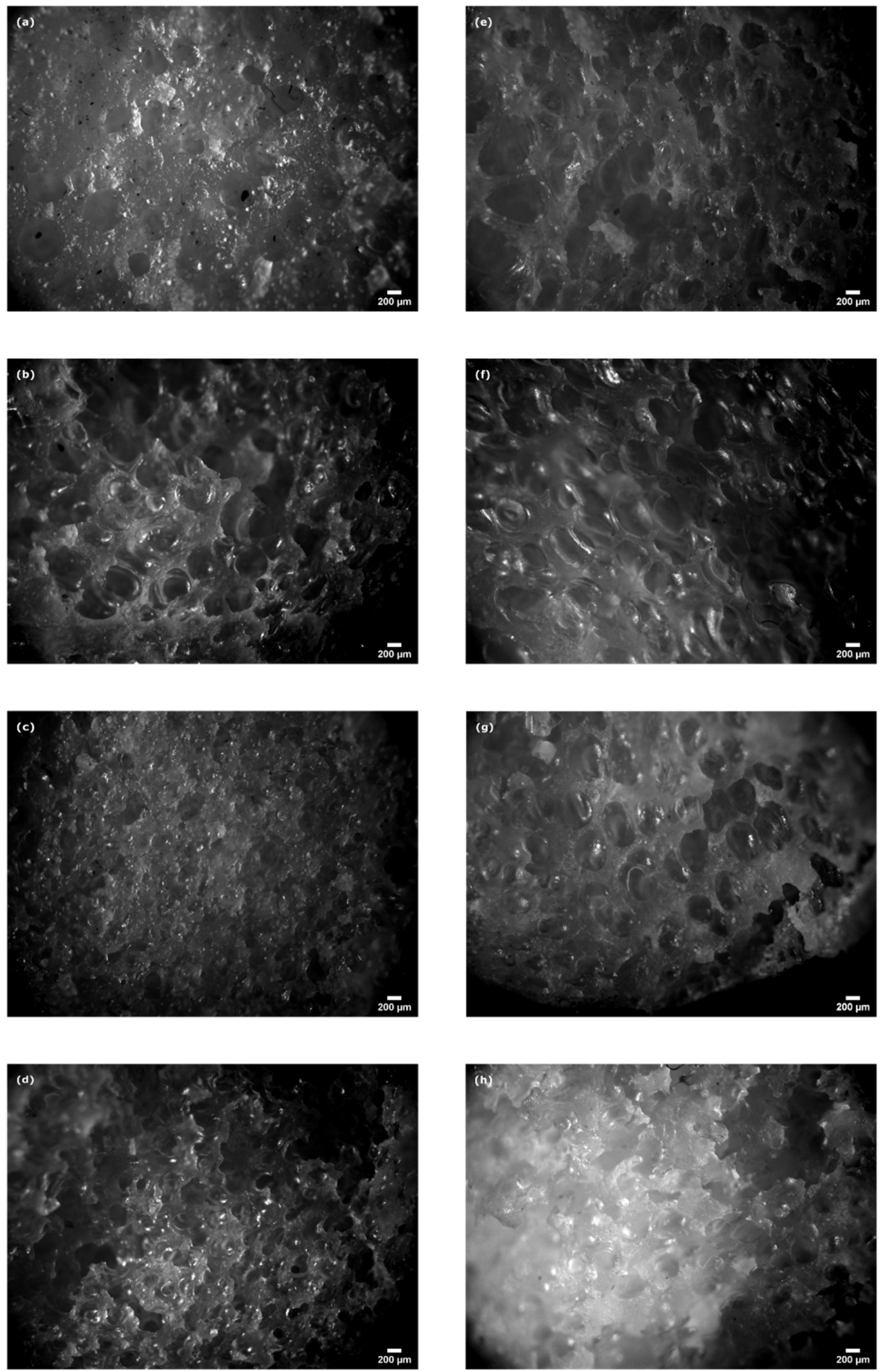

Figure 2. Micrographs of obtained foams under different process conditions: die $\mathrm{T}^{\circ}=110{ }^{\circ} \mathrm{C}$ and $4.2 \%$ CBO (a); $7.1 \%$ CBO (b); $8.5 \% \mathrm{CBO}(\mathbf{c})$ and $10 \% \mathrm{CBO}(\mathbf{d})$. die $\mathrm{T}^{\circ}=115{ }^{\circ} \mathrm{C}$ and $4.2 \% \mathrm{CBO}(\mathbf{e}) ; 7.1 \% \mathrm{CBO}$ (f) $; 8.5 \% \mathrm{CBO}(\mathbf{g})$ and $10 \% \mathrm{CBO}(\mathbf{h})$.

\subsection{Microstructural Characterization and the Relationship with the Process Conditions}

As can be seen in Figures 1c and 2, foams present large pores with significant cell size variability. The two die temperatures used did not produce any difference in the obtained cell size for CBO concentrations of 4.2 and $7.1 \%$ wt. Cell size decreased for $8.5 \%$ wt. as cell population density increased. This inverse trend is often encountered [12]. This effect is particularly significant for the $110{ }^{\circ} \mathrm{C}$ die $\mathrm{T}^{\circ}$ trial, where the average cell size was reduced by more than $50 \%$. After this point $\mathrm{N}_{0}$ decreased again and cell size increased. This can be explained as the increase of $\mathrm{CBO}$ provides more 
available gas for cell nucleaion, until a maximum is reached. With further gas increase and cell groh, cells collide against each other, reducing the $\mathrm{n}^{\circ}$ of cells and increasing their size [13] as can be observed by the trends in Figure 1b,c.

\subsection{Effect of Process Condictions on the Volume Expansion Ratio}

The two die temperatures tested were selected as a result of a preliminar process parameters screening. With die $\mathrm{T}^{\circ}$ over $120^{\circ} \mathrm{C}$, limited expansion was achieved. This is an indication for low melt strength, which impeches the polymer melt to withstand the stretching forces of the bubble growth, leading to cell collapse, and of high gas diffusion out of the polymer matrix. The lower processing temperature was conditioned by viscosity, being $110{ }^{\circ} \mathrm{C}$ the lowest temperature at which the melt would flow out of the extruder.

As it can be seen in the Figure 1a, with the die $\mathrm{T}^{\circ}$ of $110^{\circ} \mathrm{C}$, the expansion ratio increased until a maximum and then decreased. This indicated that at this temperature the expansion behaviour is governed by the polymer melt's stiffness. Expansion increases with increasing $\mathrm{CBO}$ concentration due to the plastitication effect of the gas [12]. After reaching a maximum, the gas starts diffusing out of the polymer's hot skin. For the $115^{\circ} \mathrm{C}$ die temperature serie, the maximum expansion was achieved with the lowest concentration of $\mathrm{CBO}$ tested. Since the cell size and cell population density of the samples obtained at the lowerst concentration (4.2\%) was not higher than those obtained with increasing $\mathrm{CBO}$ dosages, we can conclude that from that dosage the increased level of gas just increased the diffusion out of the hot skin of the extrudates, thus the volume expansion remained at constant levels.

During the execution of the trials, a transient situation was encountered where the die pressure was increassed from the 45 bars of the reported trials up to 75 bar. Under these conditions a higher volume expansion was obtained, and strain hardening was observed on the extrudates. The relationship between strain hardening and succesful foaming is known in the field [7], as well as the relation between pressure drop and cell population density [14]. The data of this obtained foam is not included due to the non-reproductible process conditions (transient), but shows the potential of improved foaming of this resin under optimal process conditions. As mentioned in the introduction, process optimization is out of the scope of this study, which aims and screening foamability.

\section{Conclusions}

An experimental study on the extrusion foaming behaviour of a comertial PB-1 resin was presented. Foamability of the resin was confirmed. High density foams where produced, with a volume expansion of 1.8. Processing window was screened and the influence of process conditions on the microstructure and volume expansion of the obtained foams was studied and indicated that PB-1 foam of medium density can be produced with the optimization of the foaming process.

Author Contributions: L.D. was responsible for the study design and conception, performing the experiments, analyzing the data and chiefly responsible for preparing the manuscript. I.W. provided scientific supervision of the study. Both authors contributed with the critical discusion of the results and editing of the manuscript. All authors have read and agreed to the published version of the manuscript.

Acknowledgments: The work reported is self-funded by the HafenCity University. Xihua Hu and Irina Smirnova from the Technical University of Hamburg are greatfully thanked for making the extruder available. The Hamburg Energy Research Network (EFH) is kindly acknowledged for facilityting the cooperation.

Conflicts of Interest: The authors declare no conflict of interest.

\section{Abbreviations}

The following abbreviations are used in this manuscript:

$\begin{array}{ll}\text { PB-1 } & \text { polybutylene } \\ \text { ESCR } & \text { environmental stress cracking resistance } \\ \text { DH } & \text { District heating }\end{array}$




$\begin{array}{ll}\text { PU } & \text { Polyurethane } \\ \text { TDI } & \text { toluene diisocyanate } \\ \text { MDI } & \text { methylene diphenyl diisocyanate } \\ \text { EU } & \text { European Union } \\ \text { CLP Regulation } & \text { classification, labelling and packaging of substances and mixtures regulation } \\ \text { REACH } & \text { Registration, Evaluation, Authorisation and Restriction of Chemicals } \\ \text { CBA } & \text { Chemical Blowing Agent } \\ \text { wt. } & \text { weight } \\ \mathrm{T}^{\circ} & \text { temperature }\end{array}$

\section{References}

1. Nilsson, S.F. New developments in pipes and related network components for district heating. In Advanced District Heating and Cooling (DHC) Systems; Elsevier: Amsterdam, The Netherlands, 2016; pp. 191-214, ISBN 9781782423744.

2. Kurańska, M.; Prociak, A. Bio-Based Polyurethane Foams for Heat-Insulating Applications. In Nano and Biotech Based Materials for Energy Building Efficiency; Pacheco Torgal, F., Buratti, C., Kalaiselvam, S., Granqvist, C.-G., Ivanov, V., Eds.; Springer International Publishing: Cham, Switzerland, 2016; pp. 357373, ISBN 978-3-319-27503-1.

3. CLP Regulation; (EC) No 1272/2008; Publisher: Location, 2008.

4. Commission Regulation (EU) 2020/1149 of 3 August 2020 Amending Annex XVII to Regulation (EC) No 1907/2006 of the European Parliament and of the Council Concerning the Registration, Evaluation, Authorisation and Restriction of Chemicals (REACH) as Regards Diisocyanates: (EU) 2020/1149. Off. J. Eur. Union 2020.

5. Wypych, G. Handbook of Plasticizers, 3rd ed.; Chemtec: Toronto, ON, Canada, 2017; ISBN 9781895198973.

6. Olabisi, O.; Adewale, K. Handbook of Thermoplastics; CRC Press: Boca Raton, FL, USA, 2016; ISBN 1466577223.

7. Foam Extrusion. Principles and Practice, 2nd ed.; Lee, S.-T., Park, C.B., Eds.; CRC Press: Boca Raton, FL, USA, 2014; ISBN 9781439898598.

8. Jeong, B.; Xanthos, M.; Seo, Y. Extrusion Foaming Behavior of PBT Resins. J. Cell. Plast. 2006, 42, $165-176$.

9. Schindelin, J.; Arganda-Carreras, I.; Frise, E.; Kaynig, V.; Longair, M.; Pietzsch, T.; Preibisch, S.; Rueden, C.; Saalfeld, S.; Schmid, B.; et al. Fiji: An open-source platform for biological-image analysis. Nat. Methods 2012, 9, 676-682, doi:10.1038/nmeth.2019.

10. Liu, H.; Wang, X.; Liu, W.; Liu, B.; Zhou, H.; Wang, W. Reactive Modification of Poly(ethylene terephthalate) and its Foaming Behavior. Cell. Polym. 2014, 33, 189-212, doi:10.1177/026248931403300402.

11. Reignier, J.; Gendron, R.; Champagne, M.F. Autoclave Foaming of Poly( $\varepsilon$-Caprolactone) Using Carbon Dioxide: Impact of Crystallization on Cell Structure. J. Cell. Plast. 2007, 43, 459-489, doi:10.1177/0021955X07079591.

12. Kaewmesri, W.; Lee, P.C.; Park, C.B.; Pumchusak, J. Effects of $\mathrm{CO}_{2}$ and Talc Contents on Foaming Behavior of Recyclable High-melt-strength PP. J. Cell. Plast. 2006, 42, 405-428, doi:10.1177/0021955X06066995.

13. Matuana, L.M.; Faruk, O.; Diaz, C.A. Cell morphology of extrusion foamed poly(lactic acid) using endothermic chemical foaming agent. Bioresour. Technol. 2009, 100, 5947-5954, doi:10.1016/j.biortech.2009.06.063.

14. Guo, Q.; Wang, J.; Park, C.B.; Ohshima, M. A Microcellular Foaming Simulation System with a High Pressure-Drop Rate. Ind. Eng. Chem. Res. 2006, 45, 6153-6161, doi:10.1021/ie060105w.

Publisher's Note: MDPI stays neutral with regard to jurisdictional claims in published maps and institutional affiliations. 